\title{
Checking the compatibility of embedded concrete for the production of prefabricated freight scales with the parameters declared by the supplier
}

\author{
Aleksandra Powęzka ${ }^{1, *}$, Mateusz Banaś ${ }^{1}$, and Paweł Ogrodnik ${ }^{1}$ \\ ${ }^{1}$ The Main School of Fire, Faculty of Fire Safety Engineering, 52/54 Slowackiego St., 01-629 \\ Warsaw, Poland
}

\begin{abstract}
The ready-mixed concrete is subject to certification in accordance with the compliance system $2+$. Manufacturers of concrete are required to implement factory production control and then to certify concrete, which is subject to the national mark B. The paper presents the results of strength tests of C 40/50 concrete samples. Designed according to the 23M SCC recipe, concrete has been used in the production of freight scales. The samples were subjected to "in situ" tests. As a method of quality control, a non-destructive test method for concrete strength has been proposed. A sclerometer (Schmidt type $\mathrm{N}$ hammer) was used for the tests. The research used a dynamic method of measurement by evaluating the change in the energy of the beater after rebounding from a given surface. Normal cubes with dimensions $15 \times 15 \times 15 \mathrm{~cm}$ were used for the tests. Concrete testing was carried out after the 28th day of care in accordance with the requirements of PN-EN 2390-2:2001. Based on the analysis, conclusions from the tests were formulated. The compression strength class was determined and the conformity of the hardened concrete with the parameters declared by the manufacturer was controlled. The evaluation was carried out using methods $\mathrm{B}$ and $\mathrm{C}$ for continuous production. CUSUM cumulative sum control cards and Shewhart control cards were used.
\end{abstract}

\section{Introduction}

Compliance check is an integral part of production control. Concrete properties subject to compliance checks are determined using standardized tests. The producer of ready-mixed concrete is required to check the conformity of concrete technical parameters. Concrete control is to determine whether it meets technical requirements based on the assumptions of standards $[1,2]$. The control performed by the manufacturer to assess compliance with the criterion formulated in [3] is considered as a mandatory control of the conformity of concrete. Other controls are already voluntary. They result from distrust of the supplier or

\footnotetext{
* Corresponding author: apowezka@sgsp.edu.pl
} 
they can be forced. Then, identity tests are used in which it is checked whether a specific volume of controlled concrete belongs to the same population [3-5].

The necessity to control the built-in concrete occurs when the conditions for compliant compressive strength of the concrete are not met or when errors in erected constructions are found. In this case, the concrete parameters should be checked according to the standard [6].

The sampling and testing plan as well as the criteria for the compatibility of the components of individual concretes or concrete families distinguish initial production and continuous production. Initial production covers production until at least 35 test results are obtained. It is then reclassified to continuous production, which must meet stricter compliance criteria. Standard [3] provides an additional method for assessing compressive strength using control charts [3, 5, 7-9].

Compressive strength determines the bearing capacity of the structure. Potential durability of the embedded concrete is determined on samples, cylindrical or cubic, taken during concreting. The class reliability of the structure depends not only on the quality of the concrete mix, but also on the technology of its incorporation, the method of compaction and care. The standard test is carried out after 28 days from taking the sample in accordance with the standard [10].

The purpose of the article is to characterize the methods of checking the conformity of embedded concrete in the production of goods weights and to approximate the criteria of compliance of design guidelines and standard recommendations.

\section{Methods for assessing the compliance check of concrete compressive strength, taking into account the production status}

Compatibility of compressive strength of concrete is a random control based on numerical evaluation. It is determined on samples after 28 days of maturation under standard conditions or on samples tested at the age specified in the specification. The conformity of the tested batch of concrete used for the production of freight scales with the declared strength class is confirmed after the fulfillment of the double criteria taking into account the adopted statistical quality control plan. Standard [3] distinguishes between initial and continuous production for which the sampling plan and the compliance criteria are different. The producer of goods weights assesses the conformity of the produced concrete according to the following criteria adopted for the appropriate type of production. The standard [3] provides for three methods for assessing the compressive strength of concrete (method A, B and C) depending on the production status. The conformity of the produced concrete is confirmed if both criteria are met [3-5]:

1. Criterion 1 for individual results.

Individual results of $f_{c i}$ satisfy the equation (regardless of the production status), where:

$$
f_{c i} \geq\left(f_{c k}-4\right) \mathrm{N} / \mathrm{mm}^{2}
$$

2. Second criterion regarding average results.

The average results $\mathrm{f}$ cm meet the equation depending on the production status:

- Initial production. Method A.

The average durability calculated from the set of 3 consecutive results is subject to evaluation,

$$
f_{c m} \geq\left(f_{c k}+4\right) \mathrm{N} / \mathrm{mm}^{2}
$$

- Continuous production. Method B.

The average durability calculated from at least 15 consecutive results is evaluated, 


$$
f_{c m} \geq\left(f_{c k}+1,48 \cdot \sigma\right) \mathrm{N} / \mathrm{mm}^{2}
$$

- Continuous production. Method C.

It involves the use of control cards. It can be alternatively used for conformity assessment if the continuous production conditions are set and the concrete production is covered by third party certification.

The following methods can be used to evaluate the average compressive strength test results for continuous production: compressive strength tests and control charts.

Control cards boil down to a graphical representation of the obtained control results over time. They allow observation of deviations from assumed values and detection of excessive variability of parameters measured before the occurrence of potential nonconformity $[4,11-13]$. The rules for the use of Shewhart control charts and cumulative sums (CUSUM) are given in Annex $\mathrm{H}$ of the standard [3].

\section{Characteristics of the composition of the concrete mix}

The self-compacting concrete mix used for the production of commodity scales is a multi-component composite which, under its own weight, melts and compacts, fills the formwork with reinforcement while maintaining uniformity.

For the preparation of $\mathrm{C} 40 / 50$ concrete, a coarse natural aggregate (natural gravel, rinsed) with a grain size of $2 / 8 \mathrm{~mm}$ and $8 / 16 \mathrm{~mm}$ and fine (sand washed) with a fraction of $0 / 2 \mathrm{~mm}$ was used. The sand point of the mixture is $36.9 \%$.

The application of cement to the concrete mix was determined based on the standard [14]. The water-cement ratio $(\mathrm{w} / \mathrm{c})$ of the concrete mix for the designed concrete is 0.35 . For the production of the mixture, mixing water from the aqueduct was used in accordance with the requirements [15].

Aeration of the concrete mixture was aimed at lowering internal friction, improving frost resistance, workability of the mixture and limiting the phenomenon of bleeding. To the structure of the mixture small air bubbles were introduced in the amount of $1.5 \%$ in accordance with the requirements [3].

The lime meal, due to the whiteness of the stone, was used as a filling additive. The composition of the mixture was also modified with chemical additives. ViscoCrete-20 HE accelerate hardening, increase early strength, improve fluidity, stacking and compaction. Another admixture, Stabilizer 4R, improves the stability and consistency of the mix, reduces the tendency of the aggregate to segregate and reduces the phenomenon of bleed draining water from the concrete mix. Whereas Rapid 2.1 is a new generation admixture that accelerates binding and hardening of concrete during the first day, improves workability. It does not affect the reduction of the final strength.

The tests of liquidity of the concrete mix was investigated using the precipitation cone method described in the standard [16]. The largest diameter distribution of the Abrams cone was $700 \mathrm{~mm}$. The consistency of the mixture is classified as SF 2. The density of the concrete mix is $2,393 \mathrm{~kg} / \mathrm{m}^{3}$.

The prescription concrete $\mathrm{C} 40 / 50$ meets the requirements of waterproofness according to [3], grade W8. Additionally, it meets the requirements of environmental impact on concrete during the construction's operation. According to the technological requirements defined in the standard [3], the classes of exposition for freight weights were appropriately selected: X0, XC1, XC2, XC3, XC4, XS1, XS2, XS3, XD1, XD2, XD3, XF1, XA1. Special forms of aggressive or indirect impacts resulting from attrition were taken into account. Recipe concrete is characterized by moderate abrasion. It has an abrasion class XM1. 


\section{Research agenda. Charge and examination schema}

The examination of concrete to strength compression was held in The Works Prefabrication Laboratory. The control probes to examination was selected randomly and charged from different portions of selected volume of the concrete mixture. The control probes was selected near concreting place under the effective standards $[3,7,17]$.

Certified production control of the industrial scales are conducted by producer. Agreement evaluation are conducted for individual formulas (concreate components) favored early and steady production. Production process of the industrial scales made according to $23 \mathrm{M}$ SCC formula are qualified to steady production. Frequency control of charge and examination of the point probes were 1 probe/production day. Representative strength was determined after 28 days mature period. It made at a cubic probes with dimensions $150 \mathrm{~mm}$. The probes were collected and cared to an examination time. All of the cubic probes results were evaluated.

The concrete probes verification agreement for steady production were conducted under the $\mathrm{B}$ method and the $\mathrm{C}$ method. During the examination assessed average of the minimum 15 probes and it correlated with specification declared by producer. The sclerometer method was main method to verify strength compression. As well it implemented a control card of cumulative sum and a control card of Shewhart's.

In succession during 23 days was charging 1 probe per production day. The concrete probes strength compression was examined at 28 day. A impress number was done by Schmidt's hammer, N type nr 34, 111708 produced by Swiss Proceq company for randomly selected places, located $3 \mathrm{~cm}$ above probe edge. Then at the strength machine type EDZ100 Heckert was examined strength compression. The probes surface was explored only at smooth surface from cast and it wasn't explored blurring surface [23]. A form and examination method were accordant under the effective standards [10, 24-27].

On each the probes it was selected 12 points to examination. Afterwards it were effected 5 readings at examined place all over places. It was used sclerometer by 2,25 Nm impact. It stood perpendicularly to examined surface and it tightened slowly, then a steel spike was hit into movement spindle to the concreate surface by after released spring. The hit mass backed with rate on the scale at the free a trigger up time. Ultimately impression number was read from Schmidt's hammer and that was the basis to recorded and determined the result of strength compression and it was read from following standards $[23,24,27]$.

If it is certify a contradiction during the control agreement, that should introduce systemic activities to eliminate mistakes and put production procedures right to be taken.

\section{The results from examined carried out}

The examinations was conducted under the approved program. The results are shown in tables 1-2 and figures 1-3. 


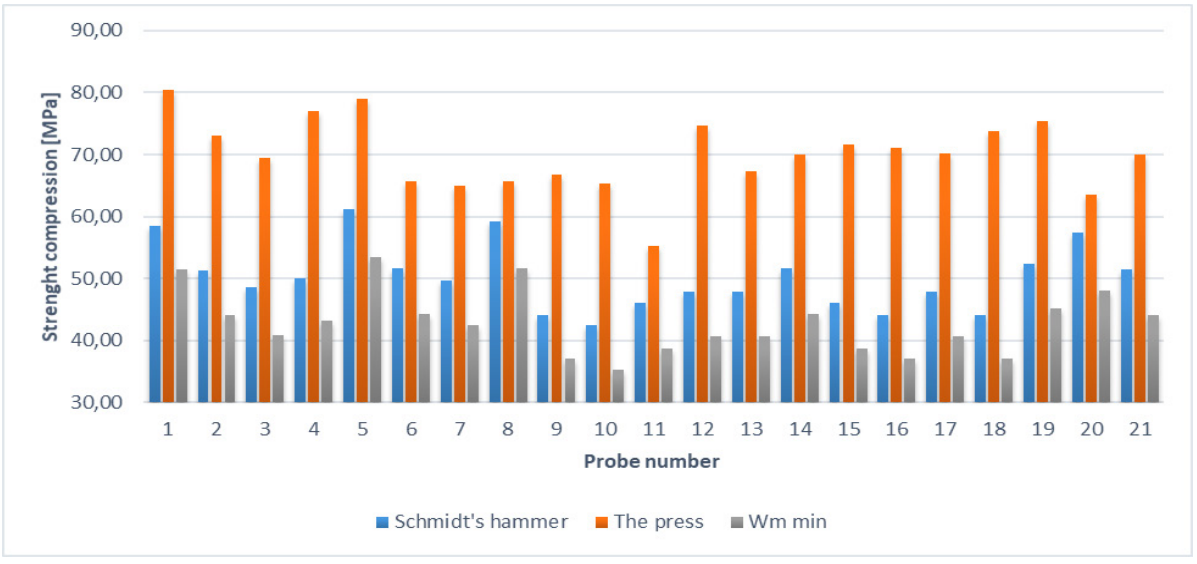

Fig. 1. The results of the examinations of strength compression fci for the C40/50 type concrete after 28 days.

Table 1. The results of examinations of strength compression - standards value, sclerometric method and damaging method.

\begin{tabular}{|c|c|c|c|c|c|c|}
\hline Method & $\begin{array}{c}\text { Mean } \\
\text { strength } \\
\mathbf{f}_{\mathbf{c m}} \\
{[\mathbf{M P a}]}\end{array}$ & $\begin{array}{c}\text { Standard } \\
\text { deviation } \\
\mathbf{S}_{\mathbf{n}}[\mathbf{M P a}]\end{array}$ & $\begin{array}{c}\text { Standard } \\
\text { deviation of } \\
\text { population } \\
\mathbf{\sigma}[\mathbf{M P a}]\end{array}$ & $\begin{array}{c}\text { Measurement } \\
\text { uncertainty } \\
\mathbf{v}[\%]\end{array}$ & $\begin{array}{c}\text { Minimal } \\
\text { strength } \\
\mathbf{f}_{\mathbf{c}, \text { min }} \\
{[\mathbf{M P a}]}\end{array}$ & $\begin{array}{c}\text { Uniformity } \\
\text { factor } \\
\mathbf{k}[\%]\end{array}$ \\
\hline $\begin{array}{c}\text { Normalized value of } \\
\text { Schmidt's hammer }\end{array}$ & 42.78 & 5.10 & 4.98 & 11.64 & 35.20 & 0.82 \\
\hline $\begin{array}{c}\text { Sclerometric method } \\
\text { (Schmidt's hammer) }\end{array}$ & 50.14 & 5.27 & 5.15 & 7.35 & 42.40 & 0.85 \\
\hline $\begin{array}{c}\text { Damaging method } \\
\text { (Hydraulic press) }\end{array}$ & 70.00 & 5.84 & 5.70 & 8.14 & 52.17 & 0.79 \\
\hline
\end{tabular}

Table 2. The results for settled class C40/50 concreate during steady production.

\begin{tabular}{|c|c|c|c|c|c|c|c|c|}
\hline \multirow{3}{*}{$\begin{array}{l}\text { Type } \\
\text { method }\end{array}$} & \multicolumn{4}{|c|}{ Mean value parameter } & \multicolumn{4}{|c|}{$\begin{array}{l}\text { Standard deviation verify for } \\
n \text { values }\end{array}$} \\
\hline & \multicolumn{4}{|c|}{ Method B: steady production } & \multirow{2}{*}{$\begin{array}{l}0.67 \sigma \\
0.68 \sigma \\
0.72 \sigma \\
0.74 \sigma \\
0.76 \sigma\end{array}$} & \multirow{2}{*}{$\begin{array}{c}\leq S_{15-19} \geq \\
\leq S_{20-24} \geq \\
\leq S_{25-29} \geq \\
\leq S_{30-34} \geq \leq S_{35} \geq\end{array}$} & \multirow{2}{*}{$\begin{array}{l}1.37 \sigma \\
1.31 \sigma \\
1.28 \sigma \\
1.26 \sigma \\
1.24 \sigma\end{array}$} & \multirow[b]{2}{*}{ Mark } \\
\hline & $\begin{array}{c}f_{c m}(21) \\
{[\mathrm{MPa}]}\end{array}$ & $\begin{array}{c}\sigma \\
{[\mathrm{MPa}]}\end{array}$ & $\begin{array}{c}f_{c k}+1.48 \sigma \\
{[\mathrm{MPa}]}\end{array}$ & Mark & & & & \\
\hline \multicolumn{3}{|c|}{ Prescription nr: 23M SCC } & \multicolumn{6}{|c|}{ Representative strenght: $f_{c k}=50 \mathrm{MPa}$} \\
\hline $\begin{array}{c}\text { Sclerometric } \\
\text { method }\end{array}$ & 50.14 & 5.15 & 57.62 & unfulfilled & 3.5 & 5.27 & 6.7 & compliant \\
\hline $\begin{array}{c}\text { Damaging } \\
\text { method }\end{array}$ & 70.00 & 5.70 & 58.44 & compliant & 3.9 & 5.84 & 7.5 & compliant \\
\hline
\end{tabular}



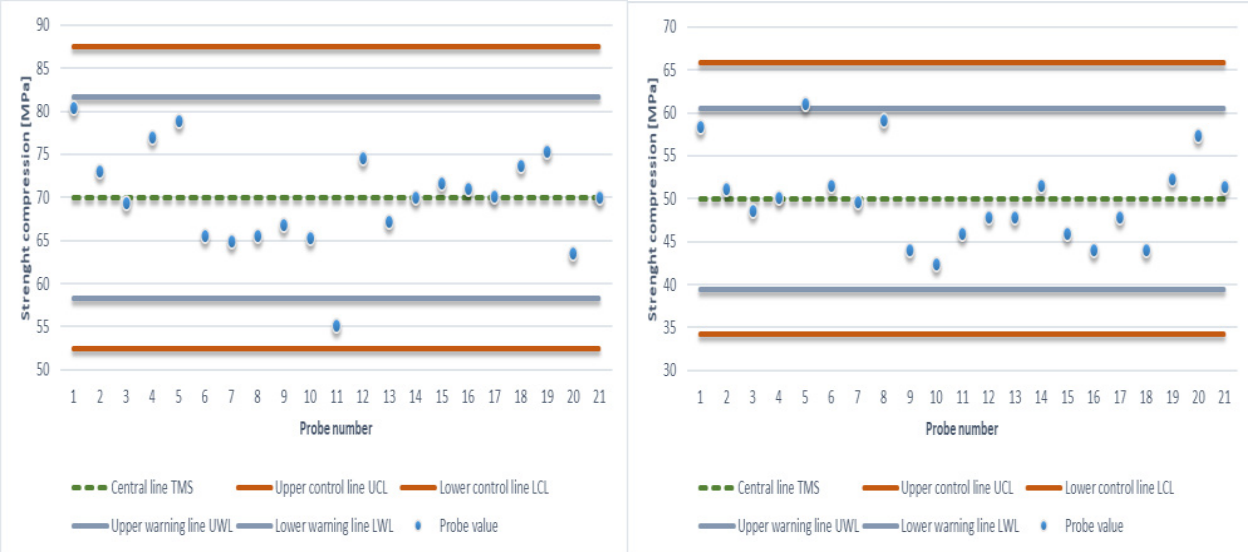

Fig. 2. The Shewhart's control card made for the class C40/50 concrete - normative probes examined through the hydraulic press (left). normative probes examined through the Schmidt's hammer (right).

The results testify about dysregulation of production are showed at figures 3 . The results form beginning of the card as well as the results from the end of the card and one value beyond warning lines are reasons to find variability of production.
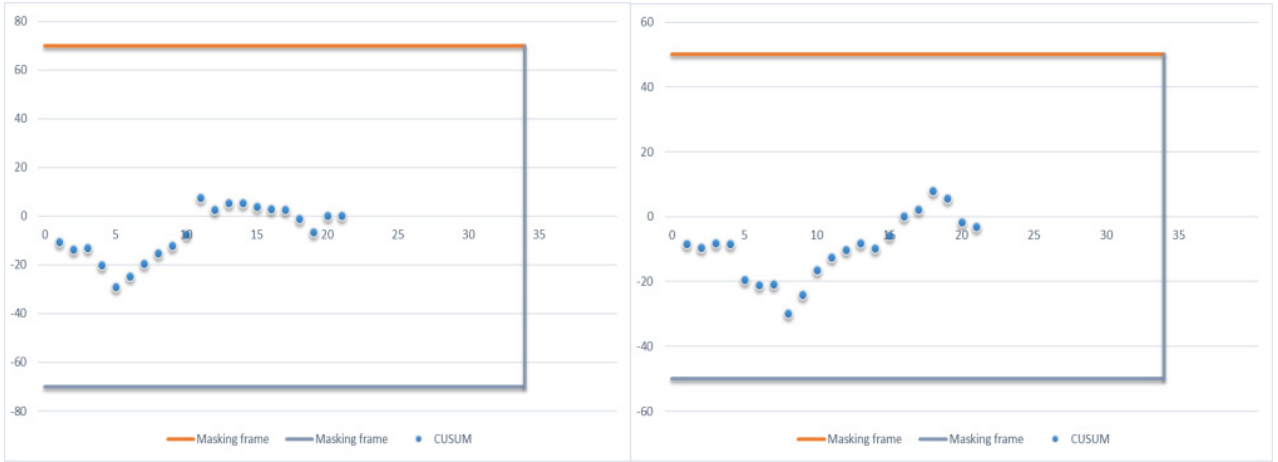

Fig. 3. The Shewhart's control card made for the class C40/50 concrete - normative probes examined through the hydraulic press (left). normative probes examined through the Schmidt's hammer (right).

In the same population values presented at the control cards assessed by B-method don't show non-compliance. A minor dysregulation are demonstrated in CUSUM cards and Shewhart's cards.

\section{Conclusions}

Evaluation of physical specification of the settled concrete are based on to bring compared early production targets. On the other hand evaluation of the concrete quality rely on analysis of the strength compression results achieved and other features of the settled concrete. The assessment is made when concrete exhibit low quality. does not comply with strength compression conditions. does not reach normative specification. In this cases real concrete parameters shall be verified. The sclerometric method allow to realize to do surface toughness of the concrete and the sufficient number of measurement are enabled. The loosening and weakened areas of the concreate can be descried by this method. In addition the application of the control cards enable to stabilize the industrial scales 
production during the process. A deteriorating excellence mistakes of the concrete products can be eliminated through the control cards.

It can be concluded on the basis of the studies and calculations carried out that:

- the average strength compression conducted by sclerometric method is $f_{c m}=50.14 \mathrm{MPa}$. standard deviation is $\sigma=5.15 \mathrm{MPa}$. minimal compression strength is $f_{\text {c.Gcub }}=42.40 \mathrm{MPa}$.

- the average strength compression conducted by damaging method is $f_{c m}=70.00 \mathrm{MPa}$.

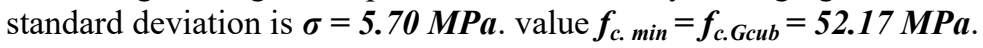

- the class of concrete can be determined by average strength compression and it's depend from guaranteed strength compression. Following the old nomenclature the class of the concrete is B 52.17 for probes destroyed by hydraulic press. The main studies showed that the class concrete is $\mathrm{C} 40 / 50$.

- the impression number depend on strength compression of the concrete. It is a main rule of sclerometric method. If the impression number is greater. the same type concrete strength is higher.

- obtaining at least 15 test results from the indirect method. without it calibration. is a good tool to determine the homogeneity of embedded concrete. Uniformity factor for sclerometric method is 0.85 and 0.79 for non-destructive method.

- the coefficient of variation is between $10 \%$ and $15 \%$. The quality if concrete is considered good due to its low coefficient of variation. The value of the coefficient of variation tends to decrease as the strength of the concrete increases.

- Shewhart's control card presents the results showing the deregulation of production. One of the 21 results is outside the warning line. It is necessary to look for the reason for this variation in the quality of production.

- from the analysis of the cumulative sum chart. it can be seen that the results obtained in this assessment period are within the limits of the designed V-mask. However. the downward trend is visible. Production is stable. but requires little integration into the production process. $t$ also forces you to constantly monitor the standard deviation.

- the sclerometric method is the easiest and the cheapest one to use. $t$ is perfect for measuring the compressive strength of embedded concrete. even though it is subject to a measurement error of $\pm 28 \%$.

- on the basis of the conformity assessment performed. the concrete can be considered compatible with the order.

Due to the use of cards and their analysis. the manufacturer has the ability to constantly monitor the quality of the product. By reading the appropriate symptoms contained in the cards. producer can make adjustments to the production process. In this way. product stabilization will be ensured.

The authors will continue to investigate the determination of a more accurate regression curve to improve the accuracy of the measurement using the sclerometric method in relation to destructive tests.

\section{Reference}

1. PN-EN 1992-1-1:2008

2. PN-EN 1994-1-1:2008

3. PN-EN 206+A1:2016-12

4. G. Bajorek. A. Golda. M. Gruszczyński. S. Kaszuba. M. Kiernia-Hnat. Z. Kohutek. J. Piotrowska-Łój, Podręcznik SPBT do znowelizowanej normy PN-EN 206:2014-04. Beton. Wymagania. właściwości. produkcja i zgodność (STBT, Kraków, 2014)

5. G. Bajorek. M. Kiernia-Hnat. Z. Kohutek, Inżynier Budownictwa 1 (2017) 
6. PN-EN 13791:2008

7. PN-EN 12350-1:2011

8. I. Skrzypczak. L. Duda-Ożóg, J. Civil Engin. Environ. Arch. 63, 157 (2016)

9. L. Brunarski, Podstawy matematyczne kształtowania kryteriów zgodności wytrzymałości materiałów (Wydawnictwo ITB. Warszawa. 2009)

10. PN-EN 12390-3:2011

11. A. Mazur-Dudzińska. J. Dudziński. XIX Międzynarodowa Szkoła Komputerowego Wspomagania Projektowania. Wytwarzania i Eksploatacji, Mechanik 7 (2015)

12. M. Sobczyk, Statystyka matematyczna (Wydawnictwo C.H. Beck, 118, 2010)

13. A. Blike, Karty kontrolne Shewharta (2011)

14. PN-EN 197-1:2012

15. PN-EN 1008:2004

16. PN-EN 12350-8:2012

17. PN-EN 2390-2:2001

18. G. Bojarek. M. Kiernia-Hnat, Builder 4 (2018)

19. A.M. Neville. Wtaściwości betonu (Polski Cement, Kraków, 2000)

20. http://www.kolej.krb.com.pl/id2/z1/dz4.html 20.09.2018

21. G. Bajorek. M. Kiernia-Hnat, Bud. Techn. Arch. 4 (2014)

22. G. Bajorek. M. Kiernia-Hnat, Bud. Techn. Arch. 1 (2013)

23. A. Powęzka. M. Banaś. P. Ogrodnik, Tygiel (to be published)

24. PN-EN 12504-2:2013-03

25. PN-EN 2390-2:2001

26. ASTM C805

27. Instrukcja stosowania młotków Schmidta do nieniszczącej kontroli jakości betonu, Instrukcja 510, ITB, Warszawa (1977) 